\title{
A lumbális gerinc lokális stabilizátorainak vizsgálata és kezelése nem specifikus derékfájdalom esetén
}

10.14232/actasana.2020.2.12-21

\begin{abstract}
ABSZTRAKT A nem specifikus derékfájdalom hátterében a gerinc lokális stabilizáló izomzatának - mint a musculus transversus abdominis (TrA) és a multifidi (MF) - funkciózavara áll. Vizsgálatunkban felmértük a lokális stabilizátorok szelektív feszítési képességét és fejleszthetőségét derékfájdalommal küzdő betegek körében. Tíz önkéntest vizsgáltunk (7 nő, 3 férfi, átlagéletkor: $25,1 \pm 1$ év). A deréktáji panaszokat az Oswestrykérdőívvel, Roland-Morris-indexszel, és Quebec Back Pain Disability kérdőívvel, illetve Vizuál Analóg Skálával mértük fel. Vizsgáltuk és a terápia során gyakoroltattuk a TrA és az MF szelektív feszítését. A feszítéseket felületes EMG-vel és ultrahanggal kontrolláltuk, az izomhas-vastagodást ultrahanggal mértük. NeuroCom Basic Balance Masterrel vizsgáltuk a statikus egyensúlyi paramétereket, a tréningprogram előtt és után. Alanyaink a funkcióvesztés mértékére vonatkozó kérdőív eredményei alapján a közepes károsodás kategóriájába tartoztak, a tréningprogramot megelőzően nem voltak képesek a TrA és az MF szelektív megfeszítésére. A kontrollált feszítés elsajátítása és gyakorlása után a mérsékelt károsodás kategóriába kerültek, fájdalmuk csökkent, képesek voltak a lokális stabilizátorokat szelektíven megfeszíteni, a statikus egyensúlyi paramétereik javultak. Vizsgálatunk eredményei alátámasztották, hogy a TrA és az MF szelektív feszítése egy jól elsajátítható módszer, továbbá, hogy a szelektív feszítésük tanítása és gyakorlása - a többi lokális stabilizáló izom funkciójának helyreállítása mellett - a nem specifikus derékfájdalmak terápiájának alapját képezheti.
\end{abstract}

ABSTRACT In the background of the nonspecific low back pain, the disfunction of the local stabilizer muscles of the lumbar spine, such as musculus transversus abdominis (TrA) and multifidi (MF) is common. Our examination aimed to assess the selective activation ability of local stabilizers and its development in patients with low back pain. Methods: Ten volunteers were examined ( 7 females and 3 males; age: $25.1 \pm 1$ year). The lumbar complaints were measured with the Oswestry Low Back Disability Questionnaire, Roland-Morris Disability Questionnaire, Quebec Back Pain Disability Scale, and Visual Analogue Scale. During the examination and the teaching of selective activation, the function of the TrA and MF was controlled with surface EMG and measured with ultrasound. Static balance parameters were recorded with the NeuroCom Basic Balance Master before and after the training program. Results: Participants were in the middle-damaged category regarding low back pain. Before the training program, they were not able neither to activate the TrA independently nor the activation of the MF. After the controlled activation program, participants were in the minimaldamaged category, the pain was decreased, they were able to activate their local stabilizer muscles and the static balance parameters were improved. Conclusion: Our examination confirmed that the selective activation of the TrA and MF is a well learnable method. Results of the study demonstrated that, besides the restoration of the other local stabilizer muscles' function, the teaching and practicing of selective activation of the TrA and MF may be the basis of the nonspecific low back pain therapy.

\section{KULCSSZAVAK non-}

specifikus derékfájdalom, neuromuszkuláris

funkciózavar, lokális stabilizátorok, musculus transversus abdominis, musculus multifidus

SZERZÖI INFORMÁCIÓ Kasza Blanka Bernadett ${ }^{1}$ és Dr. Domján Andrea ${ }^{2}$

${ }^{1}$ Szegedi Tudományegyetem Egészségtudományi és Szociális Képzési Kar, Fizioterápiás Tanszék, email:

kasza.blanka@etszk.u-szeged.hu

${ }^{2}$ Szegedi Tudományegyetem Egészségtudományi és Szociális Képzési Kar, Fizioterápiás Tanszék, email:

andrea@etszk.u-szeged.hu 


\section{Bevezetés}

A gerincfájdalom-szindrómák rendkívül gyakoriak, napjainkban nincs olyan személy, aki élete során legalább egyszer ne tapasztalt volna gerinctáji panaszokat. Jól igazolja ezt, hogy a háziorvosi gyakorlatban jelentkező mozgásszervi problémák 80\%-a gerincfájdalom-szindrómákhoz kötődik és a mozgásszervi problémával háziorvoshoz fordulók között is a derékfájdalomra panaszkodó beteg a leggyakoribb. Az esetek többségében 85-90\% - nem specifikus derékfájdalomról beszélhetünk, amelynek hátterében többnyire minimális degeneratív elváltozás áll (Apáthy és Penczner, 2011).

$\mathrm{Az}$ ágyéki gerincszakasz az egyik legmozgékonyabb, ugyanakkor a gerinc egyik leginkább igénybe vett területe, itt helyezkednek el a legnagyobb terhelésnek kitett szegmentumok. Ez a szakasz továbbítja a fej, illetve a felső végtagok súlyát a medence felé, valamint az alsó végtagok statikai elváltozásai is ezen a területen okoznak panaszokat (Szendrői, 2009). Ezek alapján érthető, hogy a gerincet érintő problémák közül a derékfájdalom az egyik leggyakrabban megjelenő fájdalom, amelyet az emberek $60-85 \%$ a megtapasztal élete során. Világszerte súlyos és kiterjedt problémáról beszélünk - mind a társadalmi, mind a gazdasági terheket nézve - bármely ország adatait is vizsgáljuk. Magyarországon az OEP (Országos Egészségbiztosítási Pénztár; 2017-től Nemzeti Egészségbiztosítási Alapkezelő) a mozgást korlátozó derékfájdalom miatt fizette a legtöbb táppénzes napot, míg a rokkantság megállapításakor is ez a harmadik-negyedik helyen megjelölt ok (Bálint, 2011).

A lumbális gerinc stabilitásáért három rendszer (aktív, passzív, idegrendszeri) összehangolt müködése felelős. A három rendszer megfelelö együttmüködése esetén optimális stabilitás, ennek hiányában azonban instabilitás jöhet létre, ami az ízületek túlterhelődését okozza és korai degeneratív folyamatok indulhatnak el. A gerinc stabilitásának károsodása miatt létrejövő kóros mozgások kihatnak a környező képletekre, hozzájárulnak a lokális stabilizátorok funkciózavarának kialakulásához. A változások hatására az ízületi mozgások a fiziológiás neutrális zónán túlhaladva jöhetnek létre (Panjabi, 1992). A fiziológiás neutrális zóna a gerinc szegmentumok neutrális helyzetéhez közeli elmozdulási tartománya, melyben az elmozdulás fiziológiásan minimális belső ellenállás mellett jön létre. A neutrális zóna megnövekedhet sérülés, ízületi degeneráció, a stabilizáló izmok gyengesége vagy diszfunkciója esetén, amely instabilitást, illetve fájdalmat okozhat. Panjabi szerint gyakran alakul ki derékfájdalom azokban az esetekben, amikor funkciókiesés, vagy nem megfelelő muszkuláris hatékonyság és neutrális zóna megnövekedése áll a panaszok háttérben (Panjabi, 1992). A gerinc stabilitásért felelős izmok a felületes-hosszú, és mélyrövid stabilizátorok. A lokális stabilizáló rendszer, mint egy gyürü veszi körbe a deréktáji szakaszt, véd a károsító szegmentális mikromozgásoktól, és azok hatásaitól. Adekvát müködésével kiegészíti a globális izmok hatását, amelyek önmagukban nem képesek megfelelően biztosítani a csigolyák közötti stabilitást. A lokális stabilizátorok fiziológiásan a végtagok mozgását megelőzve - vagy azzal egyidőben aktiválódnak - így a musculus transversus abdominis ( $\operatorname{TrA})$ is, ami a többi lokális izommal (gátizom, rekeszizom, multifidi (MF)) szinergizmusban müködve biztosítja a szegmentális stabilitást. A nem specifikus derékfájdalom hátterében legtöbbször ezeknek a stabilizátoroknak a diszfunkciója áll. Ekkor a stabilizáló funkció hiánya vagy a stabilizáló hatás késése miatt a csigolyák között szegmentálisan mikromozgások jönnek létre, a globális izmok stabilizáló hatásának ellenére is. Ezek a mozgások azonban nem a fiziológiás neutrális zónában jönnek létre, így a csigolyák közti ízületekben és az ízületet körülvevő képletekben túlfeszülés miatti irritáció, fájdalom alakul ki (Hodges, 1999) (Jull és Richardson, 2000) 
(Hodges és Richardson, 1996).

A stabilizáló izomzat müködésének helyreállítási lehetőségeit több tanulmányban vizsgálták az elmúlt években. Számos vizsgálatbanultrahangos képalkotó segítségével tanulmányozták a lokális stabilizátorok müködését. Az ultrahangkészülék - mint valós idejü képalkotó - biztonságos, költséghatékony és alkalmas a különféle szervek és szövetek vizsgálatára, így például az izom- és csontrendszerére is. Van és munkatársai (2006) kutatásukban az ultrahangot biofeedbackként használták egészséges alanyok vizsgálatánál. Eredményeik szerint a MF szelektív feszítésének tanítása során jobb eredményt ért el az a csoport, akik vizuális feedbackként használták az ultrahangot, mint az a csoport, amely nem láthatta az ultrahangot. A TrA müködését, vastagságának változását ultrahanggal vizsgáló tanulmányok alátámasztották, hogy a derékfájdalommal élő betegek esetén kisebb volt a TrA kontrakciójának mértéke és a tréning során mért izomhasvastagságváltozás a panaszmentes önkéntesek eredményeivel összehasonlítva (Endleman és Critchley, 2008). Korábbi kutatások eredményei igazolták, hogy a lokális mélyizomzat szelektív gyakoroltatásával jelentősebb javulás érhető el a derékfájdalom kezelésében, mint az általános erősítő feladatokkal, valamint, hogy a lokális izmok szelektív feszítésének újratanulása és gyakorlása hatékony terápia a nem specifikus derékfájdalom és instabilitás kezelésében (Jull és Richardson 2000) (Javadian és mtsai., 2015). A stabilizátorok reaktivációjának élettani alapja a neuroplaszticitás. Ez a jelenség lehetőséget ad arra, hogy az idegi kapcsolatok és erősségük megváltozzon, ezáltal a csökkent funkció javítható. A neuroplaszticitás az idegrendszer azon képessége, melynek során szerkezetének, kapcsolatainak vagy a funkciójának a reorganizációjával képes válaszolni külső vagy belső hatásokra. A neuroplaszticitásnak köszönhetően lehetőség van a csökkent kérgi reprezentáció visszaállítására és az újratanulásra, amit tanulmányok transzkraniális mágneses stimuláció segítségével támasztottak alá
(Tsao és mtsai, 2008) (Ruge és mtsai, 2012). Ezen eredmények alapján vizsgálatunkban a tanulási folyamatra helyeztük a hangsúlyt, a reaktivációra, azaz a neurális pályák újrahangolására.

\section{Célkitǔzés}

Vizsgálatunkban célunk annak a feltárása volt, hogy milyen kapcsolatban áll a lumbális lokális stabilizáló rendszer funkciózavara a fájdalom megjelenésével. Feltételeztük, hogy a TrA, és a MF szelektív feszítése hatékony és jól elsajátítható módszer derékfájdalommal küzdő egyének esetében. Korábbi vizsgálatok eredményei bizonyították, hogy a fájdalom, illetve instabilitás esetén valamennyi stabilizáló izomzat egyidejü, masszív, kiterjedt kokontrakciója történik, a neuromuszkuláris hatékonyság zavara miatt. Fiziológiásan a lokális izmok fiziológiás működése mellett a globális izmok müködése irányspecifikus, azaz csak az erőhatással szemben ható izomzat aktív, míg, ha károsodott a lokális stabilizáló izomzat, vagy fájdalom áll fenn, a beteg izomzata kokontrakcióval reagál. Ez az állapot gazdaságtalan túlmüködést eredményez, illetve nem védi meg kellő mértékben a kisízületeket a túlzott mikromozgásoktól (Jull és Richardson, 2000). Feltételeztük, hogy a tréning hatására javulni fog a betegek állapota, derékpanaszaik szubjektív megítélése pozitívan változik, a lokális stabilizátorok szelektív feszítésének újratanulásával, javul a neuromuszkuláris kontroll és csökken a fájdalom.

Vizsgálatok alátámasztják, hogy a stabilizációra ható feladatok növelik a TrA izomhasának vastagságát, ezáltal hatással vannak a lumbális stabilitásra, illetve az egyensúlyra. A TrA izomhasának vastagodása, valamint a statikus, és a dinamikus egyensúly paramétereinek javulása között pozitív korreláció figyelhető meg (Gong, 2013) (Hodges és Richardson, 1997). Vizsgálatunk során választ kerestünk arra, hogy igazolható-e a gyakorlás hatékonysága a TrA és az MF szelektív 
kontrakciója során az izomhas-vastagságban mért különbséggel. Vizsgálatunkban a statikus egyensúlyi paraméterek javulását vártuk a tréningprogram hatásaként. A testtömegközéppont (TTK) kitérésének csökkenését úgy tekintettük, mint a stabilitás növekedését, különösen a kar emelése, mint kibillentő hatással szemben. Feltételeztük, hogy a lokális stabilizátorok szelektív feszítésének rendszeres gyakorlása igazolható javulást eredményez a statikus egyensúlyi paraméterekben.

\section{Anyag és módszer}

\section{Alanyok}

A Szegedi Tudományegyetem tíz olyan önkéntes hallgatóját (7 nő, 3 férfi, átlagéletkoruk: 25,1 \pm 1év) vizsgáltuk és kezeltük egy 7 hetes program során, akik rendszeres, visszatérő deréktáji fájdalomra panaszkodtak. Kizáró kritériumként határoztuk meg a diagnosztizált, súlyos, neurológiai tüneteket okozó, a lumbális gerincszakaszt érintő statikai eltéréseket. Minden résztvevő a vizsgálat menetéről kapott tájékoztatás után beleegyező nyilatkozatot írt alá, melyben hozzájárultak a vizsgálat során nyert adatok anonim felhasználásához.

\section{Vizsgálati és terápiás módszerek Vizsgáló módszerek}

A deréktáji panaszok és a funkciókárosodás mértékének rögzítésére anamnézis felvételi adatlapot, az Oswestry-kérdőívet, a Roland-Morriskérdőívet, valamint a Quebec Back Pain Disability kérdőívet használtunk a program kezdetekor és végén. Vizuál Analóg Skála (VAS) segítségével rögzítettük a fájdalomérzet erősségét a 7 hetes terápia kezdetekor és végeztével, hogy figyelemmel kísérhessük a fájdalom jelenlétét, illetve annak változását, a terápia ideje alatt (Valasek és mtsai, 2013; 2015).

A TTK horizontális síkú kitérését a NeuroCom Basic Balance Master stabilometriás készülékkel, statikus erőmérő platformon vizsgáltuk. A TTK elmozdulását ülő helyzetben rögzítettük annak érdekében, hogy a poszturális kontroll során, az alsó végtagi komponensek részvételét kiküszöbölve, a törzs stabilizátorainak müködését vizsgáljuk. $\mathrm{Az}$ erőmérő platformot egy asztalon helyeztük el, a résztvevők kényelmes, laza ülő helyzetben helyezkedtek el a platformon, lábuk nem volt alátámasztva.

Négy kondíciót alkalmaztunk: nyugodt ülés, mely során mindkét kar lazán a test mellett helyezkedik el; karlendítéssel megzavart ülés (a jobb kar lendítésével, a bal kar lazán a test mellett), mely során alanyaink elöre, oldalra, majd hátra lendítették a kart és a vizsgálatok során vállmagasságban állították meg a mozgást. A TTK kitérésének rögzítése minden kondícióban $3 \times 10$ másodpercen át történt. A karlendítéssel megzavart ülés kondíciókban váratlan szóbeli utasításra kellett a kart a kondíciónak megfelelő irányba emelni, majd lassan leengedni. A stabilometriás vizsgálatot a tréningprogram előtt és után végeztük el (McGill és mtsai, 2003) (Hendershot és Nussbaum, 2013).

Ultrahangos vizsgálatot alkalmaztunk a TrA és az MF szelektív feszítési képességének vizsgálatára a tréningprogram elött a tanulás eredményességének ellenőrzésére, a tréningprogram alatt minden héten, valamint a tréningprogram után, a 8 . héten. Ultrahanggal vizsgáltukazizomhas megvastagodását a szelektív kontrakció során, illetve magát a szelektív kontrakció újratanulásának alakulását. A vizsgálatot Zonare Z.one ultra Convertible Ultrasound System készülékkel végeztük, ultrahangkészülék lineáris transzducerét használva, 4,0 cm mélyen, $12 \mathrm{~Hz}$ frekvenciát alkalmazva.

A TrA szelektív feszítésének vizsgálatával kezdtük el a vizsgálati és tanulási fázist. A szelektív feszítés ellenőrzéséhez a NeuroTrack Simplex felületes EMG készüléket használtuk negatív feedbackként. Az elektródákat a külső ferde hasizom lefutása mentén, a 7-8-as borda magasságában, illetve csontos viszonypontként a crista iliacan helyeztük el. Küszöbértékként a 
medence maximális hátrabillentése során $\mu \mathrm{V}$-ban mért érték 40 \%-át vettük, ami a külső ferde hasizmom bekapcsolódását, a szelektív feszítés sikertelenségét jelentette. A méréseket minden alkalommal azonos helyen végeztük, az EMG elektródák és a köldök által alkotott háromszög közepén, ez elülső hónaljvonal lefutásában, egyenlő távolságban az alsó bordától és a csípőlapáttól. A vizsgálat során a páciens álló helyzetben, törzs mellé engedett nyújtott karokkal, csípőszéles terpeszben helyezkedett el. Az ultrahangfejet a páciens hasfalán, oldalt helyeztük el, úgy, hogy olyan helyzetben állíthassuk meg a képet, ahol látszik a külső és belső ferde hasizom, és a $\operatorname{TrA}$ is. Az ultrahangképen kaliper segítségével mértük meg a TrA vastagságát ellazult és megfeszített állapotban is (Hodges, 1999) (Hides és mtsai, 1998).

Ultrahanggal vizsgáltuk a MF szelektív feszítését a tréningprogram előtt és után, valamint a tréning alatt, a szelektív kontrakció újratanulásának ellenőrzése során. A vizsgálat során a résztvevők hason feküdtek, a medencét párnával támasztottuk alá a neutrális helyzet biztosítása érdekében. A vizsgálatot konvex transzducerrel, $5 \mathrm{~Hz}$ frekvenciát alkalmazva a L4-5 szegmentum magasságában végeztük. Első lépésként a processus spinosusokon helyeztük el, majd oldalra csúsztattuk a fejet, párhuzamosan haladva a gerinccel, míg az ultrahangképen a processus transversus nem látható. A L4-5 szegmentum ízfelszín előtti utolsó sötét vonaltól a multifidus fascia vonaláig mértük kaliperrel az izom vastagságát (Van és mtsai, 2006).

A TrA és a MF izmok szelektív feszítését taktilis és verbális stimulációval facilitáltuk. A TrA esetén a köldök alatt, a MF esetén a fájdalommal érintett szegment(ek) területén alkalmaztuk a taktilis ingert, segítve a szelektív feszítés megéreztetését. A TrA és a MF izomhasának maximális vastagságát az izomhas legnagyobb átmérőjénél mértük, a maximális vastagságot izmonként három-három szelektív feszítés során rögzítettük (Van és mtsai, 2006).

\section{Terápia}

Kezelésünk a lokális stabilizátorok 7 hetes tréningjét foglalta magába, mely során kombinált protokollt alkalmaztunk. A Javadian és munkatársai (2015) által alkalmazott programot vettük alapul a lokális stabilizátorok bekapcsolása mellett végzett feladatokkal, míg az UH-os vizsgálati paramétereket Hides és munkatársai által 1998-ban, illetve Hodges által 1999-ben közölt tanulmányokban leírt protokoll alapján hajtottuk végre.

A szelektív feszítés elsajátítása után a TrA feszítésének gyakorlását különbözőtesthelyzetekkel, aktív felsővégtagmozgásokkal kombináltuk, UH segítségével megfigyelve a TrA és a hasizmok bekapcsolódásának sorrendjét.

A TrA feszítésének elsajátitása után a lumbális MF feszítésének elsajátítása és gyakorlása volt a feladat a panaszos szegmentek területén, ultrahangkontroll mellett. Ultrahang segítségével kontrolláltuk a szelektív feszítést oldalt fekvő, ülő és álló helyzetben. Később minden testhelyzetben (háton-, oldalt-, hason fekve, ülve, állva) fokozatosan felépítve összekapcsoltuk a gátizom, a TrA és az MF együttes, tudatos feszítését (Van és mtsai, 2006). Otthoni feladatként a szelektív feszítés gyakorlását adtuk, a cél a napi $3 \times 10$ szelektív feszítés elérése volt.

A negyedik héten a légzés kontrollját is hozzákapcsoltuk a gátizom, a TrA és az MF szelektív feszítéséhez. Később a felsővégtag mozgásait kapcsolatuk a feladatsorhoz. Célunk volt, hogy a bekapcsolódási sorrendet helyreállítsuk, a fiziológiás müködést gyakoroltassuk. A lokális stabilizátorok megfelelő időben történő bekapcsolódását - azaz végtagmozgással egyidőben vagy azt megelőzve ultrahang segítségével követtük.

Később a korábbi felsővégtagi gyakorlatokhoz már alsóvégtagi mozgást, majd komplex mozgásokat is kapcsoltunk, instabil felszínnel, csökkentett alátámasztással nehezítve a feladatokat. Minden héten kontrolláltuk az előzőleg megtanult feladatok 
helyes kivitelezését, továbbá új feladatokat adtunk otthoni gyakorlásra is.

\section{Adatfeldolgozás módszerei}

Az Oswestry-kérdőív tíz kérdést tartalmaz, kérdésenként maximum 5 pont adható, a páciens állapotától függően. A kapott pontszámból százalékszámítással kapjuk meg, hogy alanyunk a derékfájdalom és funkciókárosodás szempontjából melyik csoportba sorolható. A Quebec Back Pain Disability kérdőív a hát- és a derékfájdalomnak a mindennapi életre gyakorolt hatását vizsgálja a mindennapos tevékenységek során. Húsz kérdésből áll, és minden egyes tevékenységnél egy 0-5 közötti skála található, amit a nehezítettség függvényében kell kiválasztaniuk a betegeknek. Az értékelés során összesíteni kell a megjelölt részpontszámokat. A kimutatható minimális károsodás értéke 15 pont.

Aderékfájdalommal rendelkező betegek esetében használt Roland-Morris-kérdőív, egy 24 kérdésből álló, a „lumbális gerinc funkciócsökkenésére” specifikus, egyszerü, gyorsan kitölthető teszt, ahol az értékelés egyszerüen 0-24-ig a válaszok pontozásával történik, ahol a minimális legkisebb változás értéke 4-5 pont.

A funkciókárosodást vizsgáló kérdőívek, illetve a fájdalom mértékét felmérő skála értékelésekor az elért pontszámok átlagát és szórást számítottunk Microsoft Excel program segítségével.

A TTK kitéréséből mediolaterális (ML) és anteroposterior (AP) irányokban lengési utat számoltunk, a kondíciónként három mérés tengelyeknek megfelelő átlagos kitérését egyutas varianciaanalízisnek vetettünk alá a Statistica 12 programmal. Post hoc összehasonlításkor a Newmann-Keuls tesztet használtuk. Az adatelemzés során $\mathrm{p}<0,05$ szignifikancia szintet fogadtunk el.

A TrA és MF kontrakció alatt rögzített izomhas vastagságát Microsoft Excel program segítségével átlagoltuk.

\begin{tabular}{|l|l|l|}
\hline Kérdóivek eredményei & Tréning elött & Tréning után \\
\hline Oswestry-kérdőív & $20,7 \pm 4,58$ & $13,5 \pm 4,39$ \\
\hline Roland-Morris-kérdőív & $4,7 \pm 0,67$ & $3,2 \pm 0,63$ \\
\hline Quebec Back Pain Disability kérdőív & $10,9 \pm 1,66$ & $9,7 \pm 1,57$ \\
\hline $\begin{array}{l}\text { Visual Analóg Skála (VAS) - } \\
\text { szubjektív pontozó skála }\end{array}$ & $4 \pm 1,18$ & $2 \pm 0,45$ \\
\hline
\end{tabular}

1.táblázat: Vizsgálati eredmények változása kérdőivek esetén - tréningprogram elött és után

\begin{tabular}{|l|l|l|l|l|}
\hline Vizsgálatok eredményei & \multicolumn{2}{|l|}{ Tréning elött } & \multicolumn{2}{l|}{ Tréning után } \\
\hline & $\begin{array}{l}\text { Nyugalmi } \\
\text { állapot }\end{array}$ & $\begin{array}{l}\text { Feszített } \\
\text { állapot }\end{array}$ & $\begin{array}{l}\text { Nyugalmi } \\
\text { állapot }\end{array}$ & $\begin{array}{l}\text { Feszített } \\
\text { állapot }\end{array}$ \\
\hline $\begin{array}{l}\text { TrA izomhas vastagsága } \\
(\mathrm{cm})\end{array}$ & $0,351 \pm 0,037$ & $0,525 \pm 0,048$ & $0,354 \pm 0,038$ & $0,576 \pm 0,079$ \\
\hline $\begin{array}{l}\text { MF izomhas vastagsága } \\
(\mathrm{cm})\end{array}$ & $2,755 \pm 0,56$ & $3,123 \pm 0,52$ & $2,869 \pm 0,60$ & $3,325 \pm 0,54$ \\
\hline
\end{tabular}

2.táblázat: Vizsgálati eredmények változása izomhas vastagsága esetén - tréningprogram elött és után 


\section{Eredmények}

A fájdalom és a funkciókárosodás mértékének az alakulását a következö összefoglaló táblázatban láthatjuk (1. táblázat).

$\mathrm{Az}$ Oswestry-index értékelése alapján a résztvevők a terápia előtt a közepes, míg a terápia után az enyhe károsodás kategóriájába tartoztak. A kérdőívek (Oswestry-kérdőív, Roland-Morriskérdőív és a Quebec Back Pain Disability kérdőív, VAS) eredményei alapján, a terápiát követően csökkent a fájdalom és a korlátozottság érzése, csökkent a funkciókárosodás mértéke (1. táblázat).

A TrA és az MF szelektív kontrakciója során

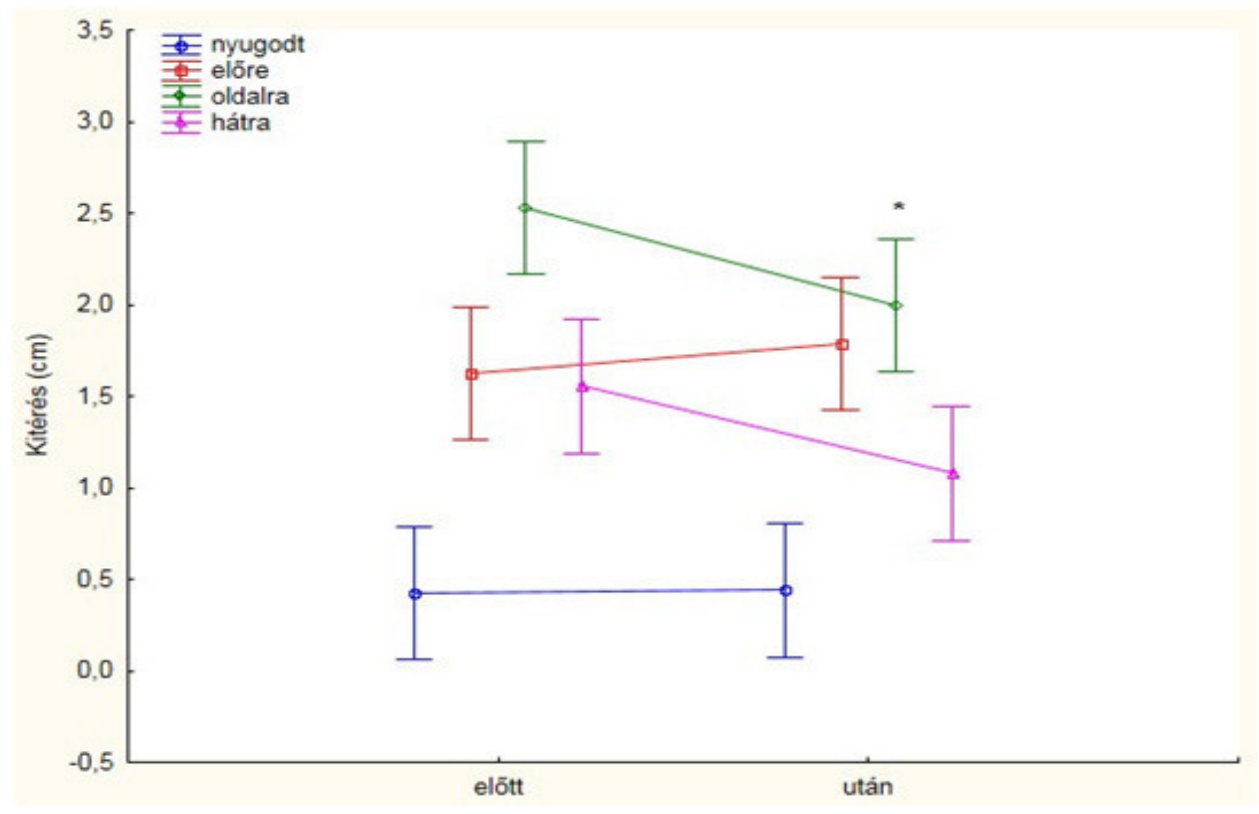

1. ábra: Lengési út változása - ML irányban nyugodt ülés és karemeléssel (elöre, hátra, oldalra) megzavart ülés során. *= a lengési út szignifikáns csökkenése a kar oldalra emelésekor a tréningprogramot követöen, $p \leq 0,05$

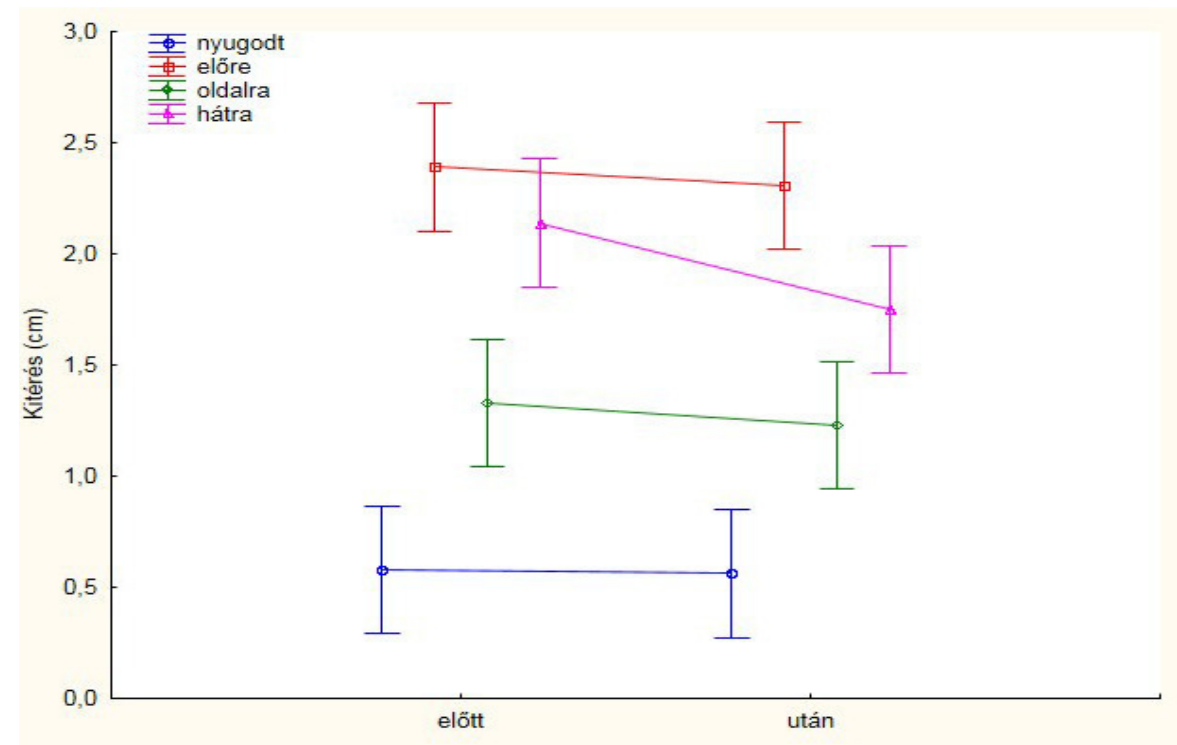

2. ábra: Lengési út változása-AP irányban nyugodt ülés és karemeléssel (elöre, hátra, oldalra) megzavart ülés során 
mért izomvastagságban növekedést tapasztaltunk a tréning előtti, és a tréninget követő eredményeket összehasonlítva (2.táblázat).

A TTK kitérése csökkent a tréninget követően. A program előtt és után kapott adatokat összehasonlítva szignifikánsan $(\mathrm{p}<0,05)$ csökkent testtömegközéppont ML irányú kitérése a kar oldalra emelése során. A kar hátraemelésekor bekövetkező ML irányú kitérés is csökkent a tréning hatására, bár a csökkenés nem volt szignifikáns (1. ábra).

A testtömegközéppont AP irányú kitérésében szintén csökkenést tapasztaltunk a tréninget követően mind nyugodt, mind a karemelésekkel megzavart ülés során, bár a változások nem voltak szignifikánsak. A kar hátraemelésekor bekövetkező kitérés jelentősen kisebb a tréning után, mint azt megelőzően, a változás közel szignifikáns ( $\mathrm{p}=0,058)$ (2. ábra).

\section{Következtetés}

Vizsgálatunk és kezelésünk során célunk elsősorban a fájdalom csökkentése volt. A fö problémára fókuszálva speciálisan választottuk meg vizsgálati és kezelési eszközeinket.

Eredményeink alapján derékfájdalommal küzdő betegeink esetén a TrA és az MF szelektív feszítésének elsajátításával együtt javult a fájdalom mértékének szubjektív megítélése is, azaz csökkent a hétköznapi mozgások közben megélt fájdalom, javult a funkció. Vizsgálatunkban a TrA és az MF stabilizáló funkciójának újratanulásával javultak a statikus egyensúlyi paraméterek is.

A nem specifikus derékfájdalom esetében a fájdalmat, instabilitást, és a funkciózavart célozzuk meg, melyen javítani szeretnénk. Krónikus derékfájdalommal küzdő egyének esetében megfigyelhető, hogy törzsizom-erősítő, illetve stabilitásnövelő program után, a derékfájdalom számottevően csökken. Korábbi tanulmányok igazolták, hogy a lokális izmok szelektív feszítésének újratanulása és gyakorlása hatékony módszer a lokális stabilizátorok diszfunkciója és a motoros kontroll megváltozása következtében kialakuló, nem specifikus derékfájdalom és instabilitás kezelésében. A stabilizációs gyakorlatok javítják a TrA funkcióját, és egyúttal az egyensúlyt is fejlesztik (Hodges, 1999) (Jull és Richardson, 2000) (McGill és mtsai, 2003).

Hides és munkatársai (1998) kutatásukban bizonyították, hogy ultrahangos képalkotó eljárás segítségével a TrA szelektív feszítése tanulható, jól elsajátítható módszer. Tapasztalatunk szerint a vizsgálat résztvevői sikeresen alkalmazták a szelektív feszítést és valamennyien képesek voltak a célul kitüzött napi 3x10 feszítést elérni az otthoni gyakorlás során. Az EMG és a vizuális feedbackként szolgáló diagnosztikus ultrahangvizsgálatok eredményei alapján úgy véljük, hogy az alkalmazott feszítések szelektívek voltak, a külső ferde hasizom összehúzódása nem kapcsolódott a TrA kontrakciójához.

Carpes és munkatársai (2008) leírták, hogy az MF vastagságának növekedésével, illetve a gátizom, TrA, MF - ultrahangos képalkotó mellett újratanult, és kontrollált - feszítésének elsajátításával és gyakorlásával csökkentek a deréktáji panaszok. Eredményeink hasonlóak, alátámaszthatják a szelektív feszítés deréktáji panaszokra kifejtett pozitív hatását.

Korábbi kutatások és saját eredményeink is azt támasztják alá, hogy a TrA és az MF diszfunkciója, valamint a krónikus derékfájdalom között összefüggés van. A lokális stabilizátorok, a TrA, az MF, valamint a gátizom légzéssel egybekötött, szelektív feszítése egy jól elsajátítható módszer, vizsgálatunkban a tréningprogram előtt mért összes paraméterben javulást tapasztaltunk.

Számos kutatás foglalkozott már az ágyéki stabilizációt és az egyensúlyt befolyásoló, a TrA funkcióját, és vastagságát érintő vizsgálattal. Ezek a vizsgálatok igazolták, hogy a TrA vastagságának növelésével az ágyéki stabilitás javítható, illetve néhány tanulmányban leírták, hogy a dinamikus 
egyensúly is javul az ágyéki stabilitás növelésével (Endleman és Critchley, 2008) (Carpes és mtsai, 2008). Vizsgálatunk eredményei felvetik a lumbális stabilizátorok statikus ülő egyensúlyban betöltött szerepét. A karlendítéssel megzavart ülésben ML irányban szignifikánsan javuló stabilitásra utaló eredmények egybecsengnek Hodges és Richardson által 1996-ban; Ainscough-Potts és mtsai. által 2006-ban közölt tanulmány eredményeivel, illetve 2013-ban Gong által közöltekkel.

Vizsgálatunk hiányossága, hogy nem ad választ arra a kérdésre, hogy a gyakorlás során hogyan változik a ferde hasizmok, különösen a belső ferde hasizom vastagsága a TrA szelektív feszítésekor. Ugyanakkor a gyakorlás során, az UH biztosította vizuális kontroll mellett azt a kontrakciót fogadtuk el szelektív feszítésnek, amikor a ferde hasizmok nem vastagodtak meg, és a felületes EMG, mint negatív feedback, nem jelezte a külső ferde hasizom bekapcsolódását.

Vizsgálatunk eredményei alátámaszthatják, hogy a nem specifikus derékfájdalom kezelése során a fájdalom csökkentéséhez elöször a lokális stabilizáló izomzat szelektív feszítését célszerü elsajátítani, majd azt funkcionális helyzetekben gyakorolni, annak érdekében, hogy helyreálljon a lokális stabilizátorok fiziológiás működése.

Összességében megállapíthatjuk, hogy a lokális stabilizátorok szelektív feszítésének elsajátítása és gyakorlása hatékony, jól használható módszer. Egyszerü, érthető feladatokat foglal magába, ezért könnyen átültethető a gyakorlatba. Időigényes, a beteg aktív részvételét, a feladatok rendszeres gyakorlását igénylő, ugyanakkor hatékony módszer, mely a többi mély, stabilizáló izom funkciójának (rekeszizom, medencefenék izmai) helyreállitása mellett, a nem specifikus derékfájdalmak terápiájának alapját képezheti.

A kutatást az EFOP-3.6.1-16-2016-00008 azonosítójú, EU társfinanszírozású projekt támogatta.

\section{Irodalomjegyzék}

Ainscough-Potts, A., Morrissey, M., \& Critchley, D. (2006). The response of the transverse abdominis and internal oblique muscles to different postures. Manual Therapy, 11(1):54-60. https://doi. org/10.1016/j.math.2005.03.007

Apáthy, Á., \& Penczner, G. (2011). A derékfájás diagnosztikája. LAM Extra Háziorvosoknak, 3 (3).

Bálint, G. (2011). A derékfájás diagnosztikájának és kezelésének modern elvei. LAM (Lege Artis Medicince), 21(5), 329-. 335.

Carpes, F. P., Reinehr, F. B., \& Mota, C. B. (2008). Effects of a program for trunk strength and stability on pain, low back and pelvic kinematics, and body balance: a pilot study. Journal of Bodywork and Movement Therapies, 12(1):22-30. https://doi. org/10.1016/j.jbmt.2007.05.001

Endleman, I., \& Critchley, D. (2008). Transversus abdominis and obliquus internus activity during pilates exercises: measurement with ultrasound scanning. Arch Phys Med Rehabil, 89(11): 22052212. https://doi.org/10.1016/j.apmr.2008.04.025

Gong, W. (2013). Correlations between Transversus Abdominis Thickness, Lumbar Stability, and Balance of Female University Students. Journal of Physical Therapy Science, 25(6): 681-683. https:// doi.org/10.1589/jpts.25.681

Hendershot, B. D., \& Nussbaum, M. A. (2013). Persons with lower-limb amputation have impaired trunk postural control while maintaining seated balance. Gait \& Posture, 38(3):438-42. https://doi. org/10.1016/j.gaitpost.2013.01.008

Hides, J. A., Richardson, C.A., \& Jull, G. A. (1998). Use of the real-time ultrasound imaging for feedback 
in rehabilitation. Manual Therapy, 3(3), 125-131. https://doi.org/10.1016/S1356-689X(98)80002-7

Hodges, P. (1999). Is there a role for transversus abdominis in lumbo-pelvic stability? Manual Therapy, 4(2), 74-86. https://doi.org/10.1054/ math.1999.0169

Hodges, P., \& Richardson, C. (1997). Feedforward contraction of transversus abdominis. Experimental Brain Research, 114, 362-370. https:/doi. org/10.1007/PL00005644

Hodges, P., \& Richardson, C. A. (1996). Inefficient muscular stabilization of the lumbar spine associated with low back pain. Spine, 21: 2640-265. https:// doi.org/10.1097/00007632-199611150-00014

Javadian, Y., Akbari, M., Talebi, G., TaghipourDarzi, M., \& Janmohammadi, N. (2015). Influence of core stability exercise on lumbar vertebral instability in patients presented with chronic low back pain: A randomized clinical trial. Caspian Journal of Internal Medicine, 6(2):98-102.

Jull, G., \& Richardson, C. A. (2000). Motor control problems in patients with spinal pain: a new direction for therapeutic exercise. Journal of Manipulativeand Physiological Therapeutics, 25(2):115-7. https:// doi.org/10.1016/S0161-4754(00)90079-4

McGill, S. M., Grenier, S., Kavcic, N., \& Cholewicki , J. (2003). Coordination of muscle activity to assure stability of the lumbar spine. Journal of Electromyography and Kinesiology, 13(4):353-9. https://doi.org/10.1016/S1050-6411(03)00043-9

Panjabi, M. (1992). The stabilizing system of the spine part I. Function, dysfunction, adaptation and enhancement. Journal of Spinal Disorders, 5:(4), 383-38. ttps://doi.org/10.1097/00002517199212000-00001
Panjabi, M. (1992. Dec.). The Stabilizing System of the Spine. Part II. Neutral Zone and Instability Hypothesis, Dec;5(4):. Journal of Spinal Disorders, 5(4), 390-6. https://doi.org/10.1097/00002517199212000-00002

Ruge, D., Liou, L., \& Hoad, D. (2012). Improving the Potential of Neuroplasticity. Journal of Neuroscience, 32(17):5705-5706. https://doi. org/10.1523/JNEUROSCI.0430-12.2012

Szendrői, M. (2009). Ortopédia. Semmelweis Kiadó és Multimédia Stúdió.

Tsao, H., Galea, M. P., \& Hodges, P. (2008). Reorganization of the motor cortex is associated with postural control deficits in recurrent low back pain. Brain, 131(8):2161-71. https://doi. org/10.1093/brain/awn154

Valasek, T., Varga , P., Szövérfi, Z., Kümin , M., Fairbank, J., \& Lazary, A. (2013). Reliability and validity study on the Hungarian versions of the oswestry disability index and the Quebec back pain disability scale. Eur Spine J., 22(5): 1010-1018. https://doi.org/10.1007/s00586-012-2645-9

Valasek, T., Varga, P., Szövérfi , Z., Bozsodi, A., Klemencsics, I., Fekete, L., \& Lazary , A. (2015). Validation of the Hungarian version of the Roland-Morris disability questionnaire. Disability and Rehabilitation, 37(1):86-90. https://doi.org/10 $.3109 / 09638288.2014 .909536$

Van, K., Hides, J. A., \& Richardson, C. A. (2006). The Use of Real-Time Ultrasound Imaging for Biofeedback of Lumbar Multifidus Muscle Contraction in Healthy Subjects. Journal of Orthopaedic and Sports Physical Therapy, 36(12):920-5. https://doi.org/10.2519/ jospt.2006.2304 